Historic, archived document

Do not assume content reflects current scientific knowledge, policies, or practices. 

UNITED STATES DEPARTMENT OF AGRICULTURE

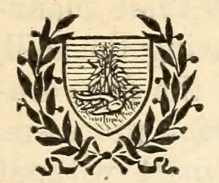

BULLETIN No. 904

Contribution from the Bureau of Plant Industry

WM. A. TAYLOR, Chief

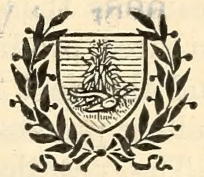

Washington, D. C.

PROFESSIONAL PAPER

October 29, 1920

\title{
THE PRODUCTION AND UTILIZATION OF CORN OIL IN THE UNITED STATES.
}

\author{
By A. F. Sievers, \\ Chemical Biologist, Drug, Poisonous, and Oil Plant Investigations.
}

CONTENTS.

Page.

Origin of the corn-oil industry ...............

Degerminating corn......................

Methods of degermination used...............

Expelling the oil from corn germs...........

Handling and disposing of the crude oil......

Handling and disposing of the oil cake.......

Buying and shipping corn germs ............

Utilization of corn oil.

Effect of color and condition of the corn on the yield and character of the oil............. $\quad 15$

Comparison of the oil-production operation in different mills........................ 16

Economies of corn-oil production............ 17

Cost of expelling corn oil.................... 17

Production of edible oil.................... 20

The future of corn oil................... $\quad 22$

\section{ORIGIN OF THE CORN-OIL INDUSTRY.}

The production of corn oil from the germ of corn kernels has been practiced on a commercial scale for probably a quarter of a century. From the time the degermination of corn became an integral operation in the hominy, starch, and glucose industries, the disposition of the germ has been a decided factor in the economics of these processes. At first the general practice was to dispose of the germ material by adding it to feed products, but as the demand for vegetable oils increased, for both edible and technical uses, it was found profitable to expel the oil from the germ, and in recent years when oils have been high in price the production of corn oil has become one of the important phases of the corn-products industries.

\section{DEGERMINATING CORN.}

The germ of the corn represents approximately 10 per cent of the dry kernel and contains about 50 per cent of oil. It has been found that this amount of fat, representing about 5 per cent of the air-dried

$$
2467^{\circ}-20-1
$$


corn, has a tendency to become rancid when allowed to remain in the corn product, especially in the presence of moisture. It became desirable therefore to remove the germ in order that these manufactured products might retain their quality after leaving the mill, and this fact has led to the scientific development of the dry cornmilling process and the starch and glucose manufacturing processes.

The practice of grinding the whole kernel into meal without previously removing the germ is confined largely to the South, and the product is sometimes referred to as "water-ground" meal. There is considerable difference of opinion as to the relative nutritive value and flavor of the products from the whole and the degerminated corn, but if the products are to be shipped extensively the removal of the germ minimizes the loss from spoilage in transit and in storage.

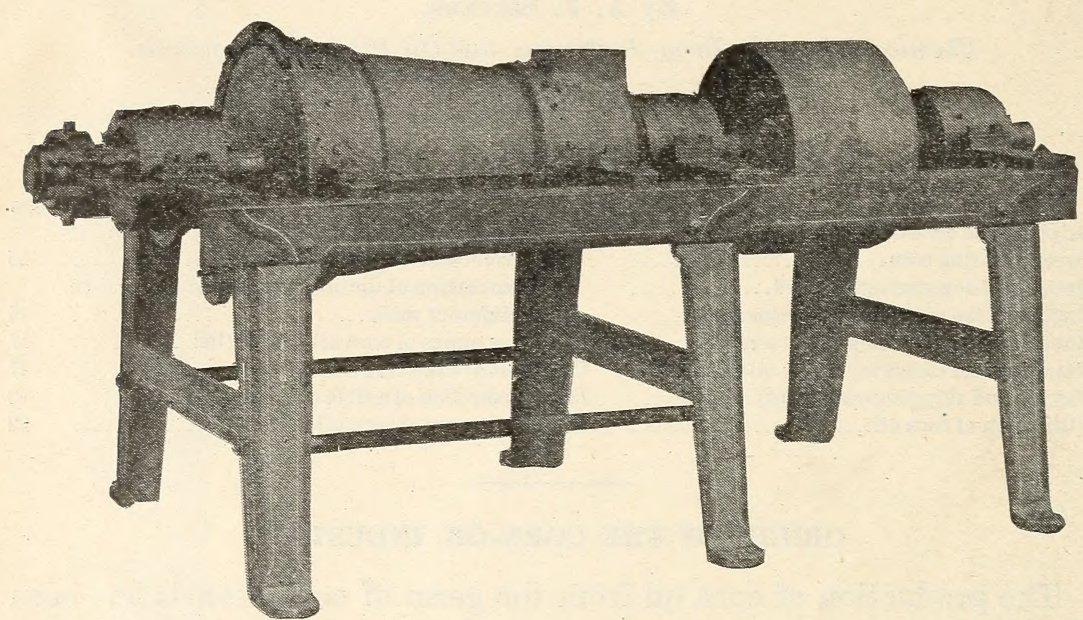

FÍx. 1.-Corn huller or degerminator. This type of machine is quite generally used in the dry degerminating process.

The percentage of moisture present is of vital importance, and millers aim to reduce the moisture in their products to 12 per cent or less, in which case it is claimed that under normal conditions little difficulty is likely to be experienced in keeping the products. Cereal products are liable, of course, to infestation with weevils, and it is not probable that the removal of the germ from the corn will lessen this trouble to any considerable extent.

\section{METHODS OF DEGERMINATION USED.}

The methods of manufacturing corn products fall into two classes: The dry milling process, used for making hominy products, such as grits, flakes, meal, flour, and hominy feeds; and the wet process, used in the manufacture of starch, glucose, and related products. The methods of degerminating differ materially in these two processes, and they will therefore be considered separately. 
DRY PROCESS.

After a process of cleaning to remove the dirt and foreign matter, the corn, while being agitated in a suitable container, is sprayed with water or treated with steam until it has a moisture content of about 20 per cent, after which it goes at once into the degerminating machine. (Fig. 1.) This machine consists, briefly, of a horizontal, tapering drum, which revolves on a central shaft within a casing of the same shape. The surface of the drum, or core, is covered with cone-shaped protuberances about three-fourths of an inch high, and the interior of the casing has a similar surface. A space of sevensixteenths of an inch is allowed between the two surfaces, and the core is rotated at 700 revolutions per minute. The space between the core and the casing can readily be adjusted while the machine is in operation. The corn enters at the top and narrow end of the

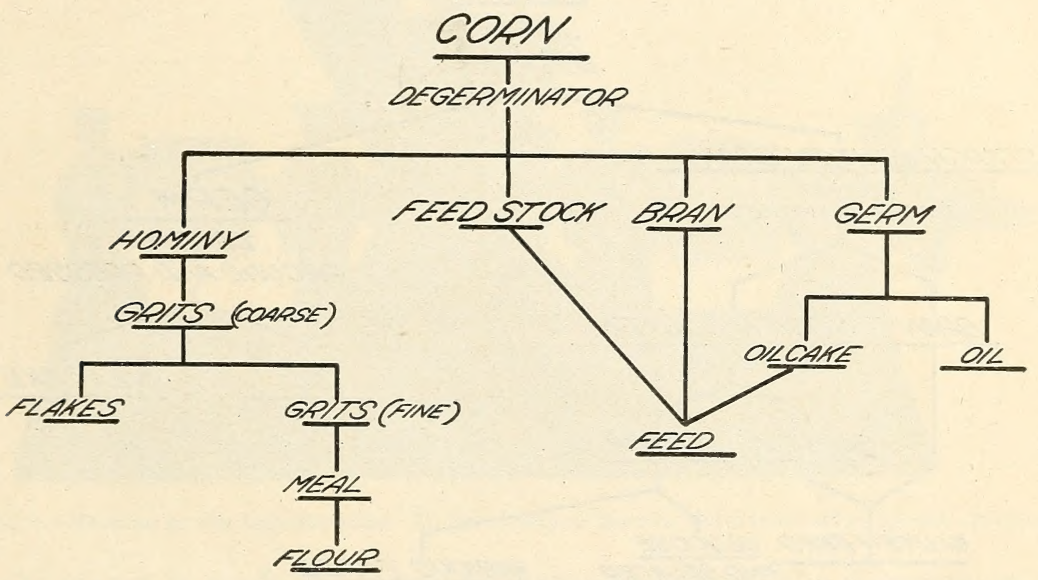

FIG. 2.-Diagram showing the various steps in the process of the dry milling of corn products in a hominy mill.

machine and is carried forward through the length of the revolving: core. During its passage through the machine the kernel is torn and shredded, the husk and germ are loosened, but the starchy material is not ground to any considerable extent. The finer particles escape through perforations, while the coarse material escapes at the discharge end. The bran is partly drawn off by suction.

The germ thus separated contains some bran, husks, and meal, the quantity depending on the uniformity of the corn and the care practiced in the operation. This germ material is then run through drying machines, where the moisture is reduced to about 14 per cent, after which it is usually run through hominy reels. With the decrease of moisture more bran and feed stock (a poor grade of grayish meal containing some bran) are separated. The germ is then ready to go to the oil-expelling department. This is not the procedure followed in all mills, but the principle is the same in all. Figure 2 shows the general scheme of dry corn milling. 
In most hominy mills the hominy products are the principal ones, while the feed, flour, meal, and oil are minor or by-products. Until recently the principal consumers of hominy products were the brewers, who used flakes and large quantities of grits of various sizes. These flakes are made from coarse hominy (pearl hominy), which is steamed, rolled, and dried. They are white and differ from the ordinary breakfast flakes mainly in the fact that they are not toasted. In the ordinary milling practice about 5 per cent of the corn kernel is made into flour. This amount develops incidentally during the process, owing to the breaking up in the various machines of the starchy and brittle portions of the kernel. Whenever the market demands warrant, however, the production of flour can be increased by reducing:

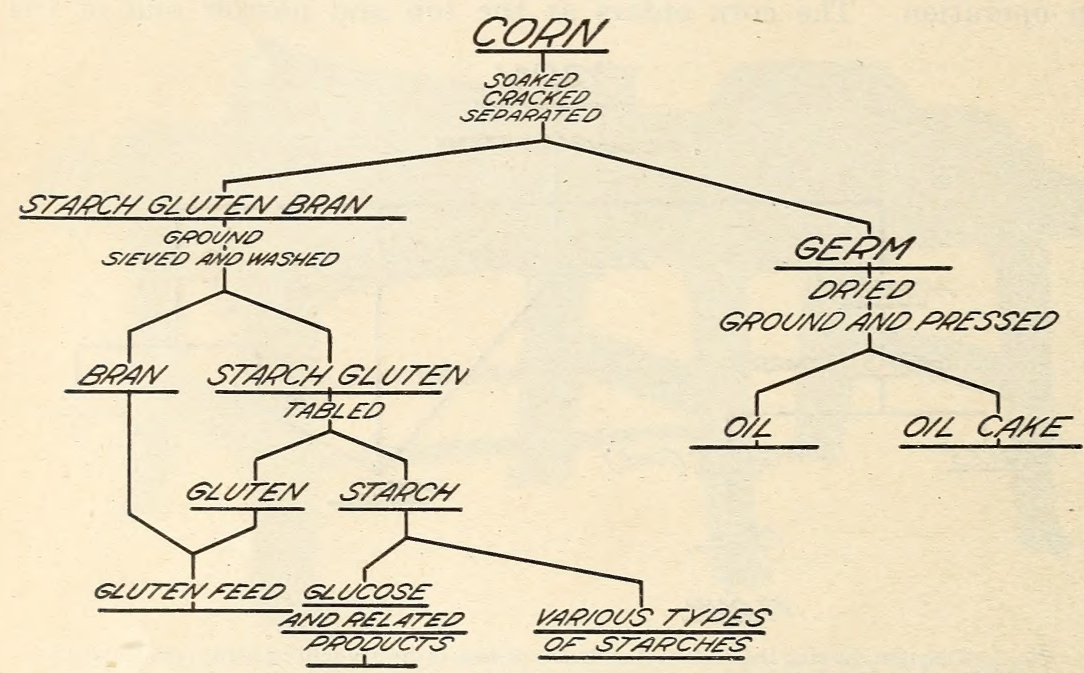

FIG. 3.-Diagram showing the various steps in the process of the manufacture of products from corn in a glucose plant.

more of the grits. During the war the demand for wheat-flour substitutes resulted in a greatly increased production of corn flour and meal.

WET PROCESS.

In starch and glucose plants the corn is degerminated by the wet process. The cleaned corn is placed in large circular wooden vats, which are filled about two-thirds full, where it is steeped or soaked in water containing 0.2 per cent of sulphurous acid. This acid is usually prepared by burning sulphur and passing the fumes of sulphur dioxid through coke towers in the presence of a spray of water. In some plants there is an arrangement to draw off the corn gradually at the bottom and to put in fresh corn at the top of the vat. The time required to prepare the corn properly for degerminating varies from 36 to 40 hours; hence in the automatic arrangement that much 
time should be required for the corn to travel from the top of the vat to the outlet below.

The object of using the sulphurous acid appears to be a matter of some dispute. The following reasons have been advanced for its use: (1) It softens the corn more than plain water, and hence aids in degerminating; (2) it acts as a bleaching agent and insures a whiter starch; and (3) it acts as a preservative and prevents the starch and gluten waters from becoming sour. The acid is largely dissipated during the processes that follow, but the finished product should not contain more than a mere trace of sulphur dioxid.

Figure 3 shows in a general way the variety of products made in a plant equipped for the manufacture of glucose. In plants where

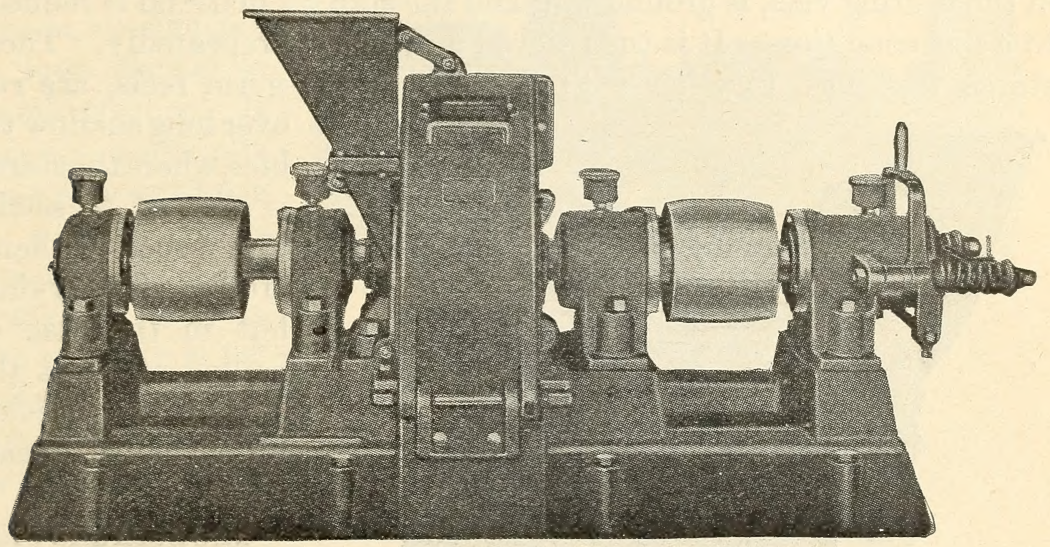

TIG. 4.-Machine for wet degerminating. In this machine the two plates revolve in opposite directions.

only starch is made the general scheme as regards the degerminating is the same.

The soaked corn is drained and then passed through a type of attrition mill, which shreds it and separates the germ from the remainder of the kernel and also loosens the hulls from the endosperm. The type of machine generally in use consists of two vertical plates mounted on a horizontal axis and geared directly to a motor. In the early type of machine the two plates were geared to different motors and revolved in opposite directions. (Fig. 4.) In some instances they were run at different rates of speed, apparently with good results. The latest approved type, however, has one stationary plate. This eliminates one motor and greatly reduces the cost of the machine as well as the operating expense. (Fig. 5.)

The shredded corn is mixed with a large quantity of water and transferred to floating vats, which are long, narrow, metal vessels somewhat wider at the top than at the bottom. The watery mixture is slowly agitated and kept moving at the surface toward one 
end of the vat. Most of the germs float on the surface and over the edge of the vat at one end. The bulk of the germ material is thus removed, but in the larger plants the remaining material is put through another floating vat and additional germs are separated. The germs, together with a lot of starchy water, are then run through reels having perforated copper sides, with the perforations about $1 \frac{1}{4} \mathrm{~mm}$. in diameter. Here they are thoroughly washed to remove all starchy particles. The washings from these reels are run through a second set of reels having finer perforations, which catch the small germ fragments that passed through the first reel. The quantity of germ material thus recovered is very considerable.

The corn material, which because of its greater gravity remains in the floating vats, is ground wet, and the starchy material is reduced to a fine condition. It is then sieved and washed repeatedly. These starch washings, together with those from the germ reels, are run



FIG. 5.-Machine for wet degerminating. In this machine one plate is stationary. over long shallow tables, where thestarch is allowed to settle. The process thereafter is one of drying, but in the case of boiling starches the drying is preceded by chemical treatment.

The husk and bran from which the starch has been washed are run

through moisture expellers to remove part of the moisture and are then mixed or churned with the concentrated steep water from the steeping vats. This water, which contains considerable quantities of water-soluble proteins, is previously pumped into a vacuum tank and evaporated under reduced pressure. The evaporation is accomplished under a vacuum of about 26 inches, part of which is obtained by passing all the waste water of the plant through a special attachment, like a Venturi tube. The higher vacuum is secured with a power pump. As above stated, this protein water, to which is also added in some plants the gluten which tabled out at the lower end of the starch settling tables, is mixed with the feed material and the mixture pumped through filter presses. The press cakes from these filters are broken up by running them through mills. The material is then sent through driers. These driers are also used for drying the germs and will be described in that connection. After becoming partially dry the material, which has become 
agglutinated into small round balls, is passed through thrashers, which break up the balls, and then passed again through the driers until the moisture has been sufficiently reduced.

After all the germ material has been separated in the manner described and washed free from starch it is run through moisture expellers to take out some of the excess water. The machines used are the same as those employed for expelling moisture from the feed material. Two types are in use. One consists of two vertical plates operated separately and so attached to separate shafts that the space between the plates at the bottom is much less than at the top. The wet material is caught in this constriction and the excess water squeezed out. (Fig. 6.) The other type is constructed on lines similar to an oil expeller. It consists essentially of a worm revolving in a steel barrel through which the material travels. The pressure is adjusted by means of a steel cone at the forward end of the machine. (Fig. 7.) The quantity of water left in the germs after passing

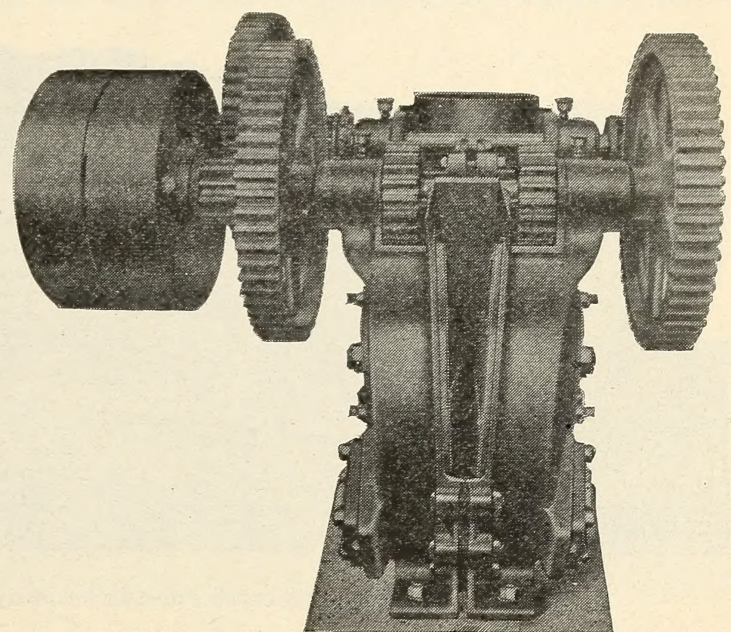

FIG. 6.-One type of machine used for expelling moisture from wet germs and feed. through these ma-

chines depends largely on the pressure applied. After the excess moisture has been removed, the germs are conveyed to the driers, which reduce the moisture to 5 per cent or less. These driers are also used for drying feed.

In hominy mills the germs are also dried, but apparently not to such a degree. For this purpose there is in use one main type of drier which has been revised from time to time. (Fig. 8.) The oldest form consists of a long cylinder or drum about 5 feet in diameter and 28 feet long. On the inside of this cylinder, around the circumference, are parallel steam pipes 4 inches in diameter, and the whole apparatus slowly revolves. The steam enters through an opening in the central shaft, while the material to be dried enters at one end and travels slowly down the length of the machine, as the farther end is somewhat lower than the forward end. The material rolls and tosses between the hot steam pipes, and by means 
of vanes on the inside of the cylinder is carried partly up the side and then tumbled back among the pipes. These driers appear to be efficient and are generally used for this purpose. Improvements have been added from time to time, but the basis of operation is the same. After being dried, the germs are ready to go to the expelling plant.

\section{EXPELLING THE OIL FROM CORN GERMS.}

While the method of handling and degerminating the corn is totally different in the dry and the wet processes, the operation involved in handling the germ material after it is dried and ready for the oil machinery is the same for both processes. At this point

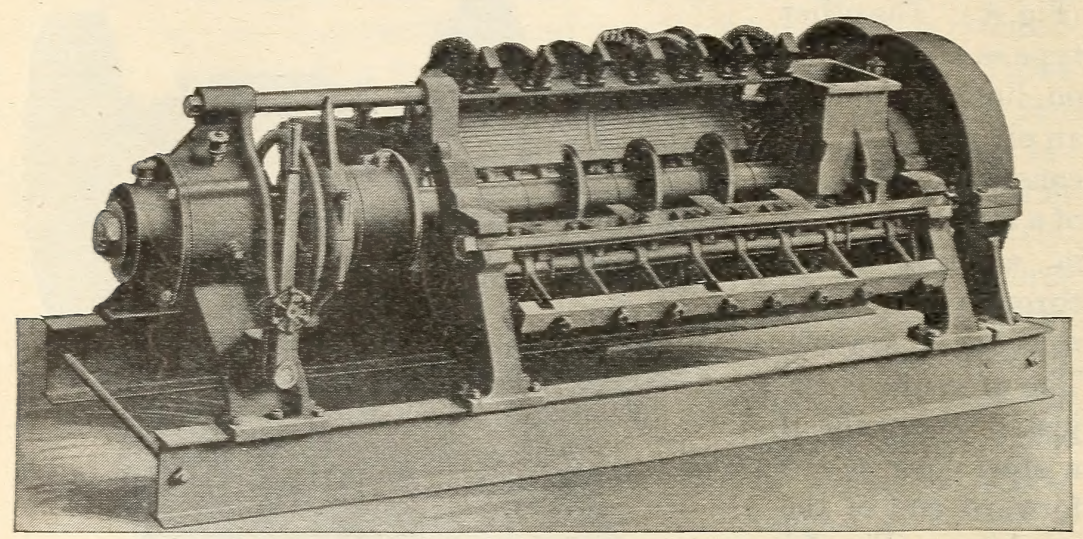

Fig. 7.-A type of moisture expeller used for wet corn germs and feed.

it is logical to discuss the difference in the germ material as obtained by the two processes.

The germs separated by the dry process contain considerable portions from other parts of the corn, which on an average reduce the oil content to about 18 per cent. Approximately 6 per cent of oil remains in the cake. Dry-corn millers agree that half a pound of oil is an average yield from a bushel of corn, and if 12 per cent of oil from the germ is representative it follows that 4.17 pounds of germs are obtained from a bushel of corn.

The germs separated by the wet process are much cleaner-that is, they contain much less of the other parts of the corn, and therefore average a much higher percentage of oil, or about 45 per cent. It is not usually possible, however, to obtain a cake with as low an oil content as that obtained by the dry process. The cake usually contains about 9 per cent of oil. Assuming that $1 \frac{1}{4}$ pounds of oil represent the average yield from a bushel of corn, and that 36 per cent is obtained from the germ, the germ material obtained from a bushel of corn must be about 3.47 pounds. 
These figures relating to the quantity of germs and oil obtained from a bushel of corn are considered fairly representative and will be used in a later section on the economics involved in expelling the oil.

Before the oil can be expelled the germ material must be cracked or ground. The germs from the dry process are ground less fine, as a rule, than those obtained from the wet process. The former, which contains some bran and husks, can be ground in an attrition mill if necessary, but in most cases all germ material is cracked by being passed between rollers.

Without doubt the expeller is recognized as the ideal type of machine for removing the oil from corn germs and is almost univer-

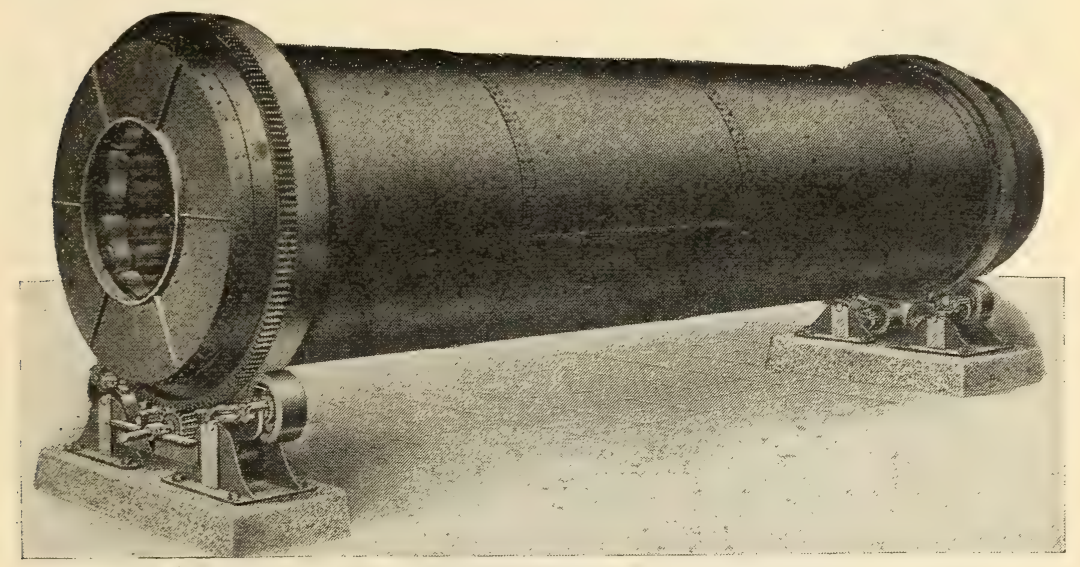

FIG. 8.-Type of drier used in drying corn germs and feed.

sally used. (Fig. 9.) The dried germ is tempered with steam, which heats it and also adds moisture. It might seem that if there were less drying in the first place the subsequent addition of moisture would be unnecessary, but it is evidently a case of first removing the interior moisture and then adding surface moisture when tempering. On this point operators are agreed.

The pressure at which these machines are operated determines largely the quantity of oil left in the cake. Several factors are involved which limit the pressure that can safely be maintained. In the first place, increased pressure always involves a decrease of capacity. Furthermore, the opinion obtains generally that if the pressure is too great the oil and cake will both darken, which is very undesirable. The wear and tear on the machine is also excessive under such circumstances, and consequently, as a rule, no effort is made to reduce the oil in the cake below 5 per cent when operating $2467^{\circ}-20-2$ 
on germs from the dry process and below 8 per cent when using material from the wet process.

A peculiar series of explosions often takes place in these expellers, mostly when used on germs obtained by the dry process. The cause does not appear to be well understood, but it is the general opinion that an excessive or an insufficient amount of either moisture or fiber is responsible.

The oil obtained, which in most cases is of a golden color, is next passed through filter presses which remove the fine meal. This

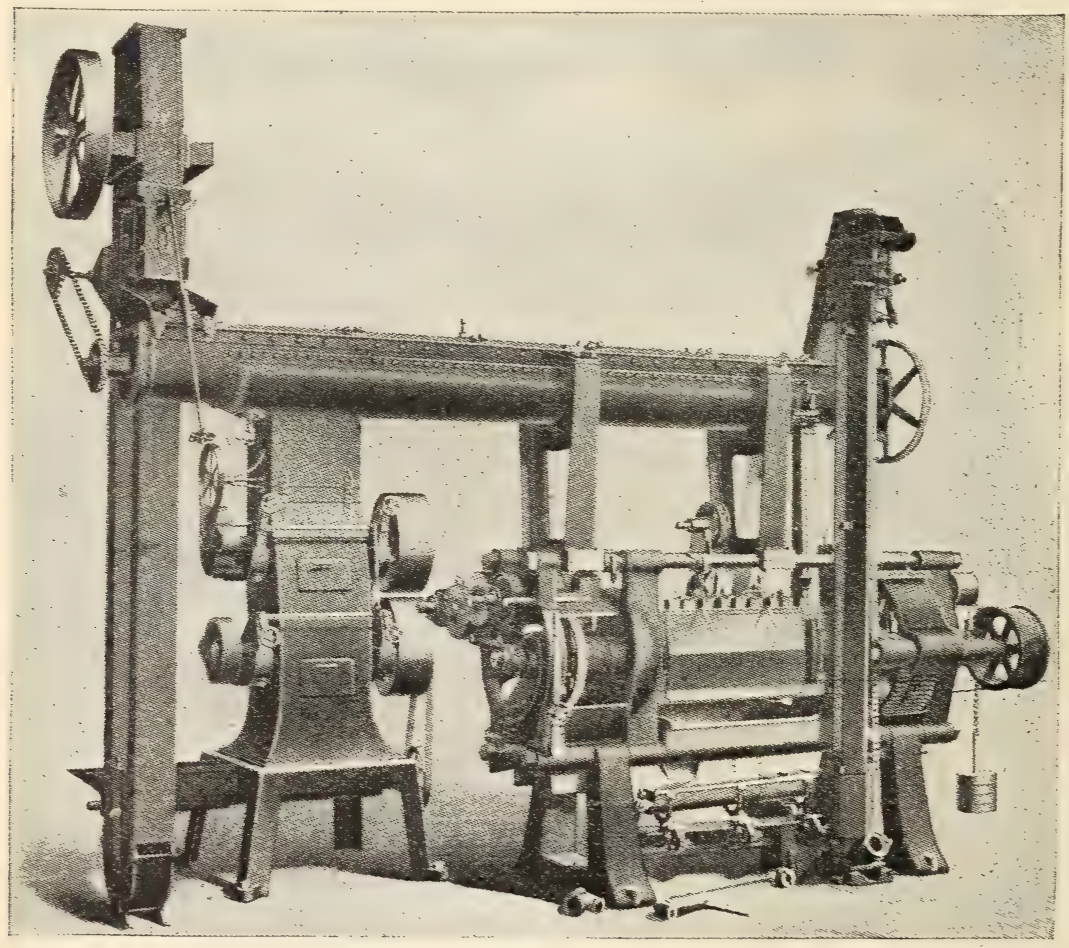

Fig. 9.-Complete 1-expeller oil plant.

meal is then returned to the expellers and mixed with the fresh material.

Hydraulic presses are used only to a very limited extent, having been almost entirely displaced by expellers. The question of the relative expense of operating presses and expellers is interesting, and several factors are involved. The cost of operating presses is somewhat increased at present (1920) owing to the expense of the press cloths, which cost about $\$ 2$ a yard. It is estimated that the entire set of cloths must be replaced every 60 days, and since 45 yards are required for one press of 15 plates, this item amounts to $\$ 90$, or $\$ 1.50$ 
a day for each press. These figures do not include the cost of repairing the cloths, which must constantly be done in order to make the set last 60 days. In the expellers this expense is eliminated. It is estimated that the cost of repairs on an expeller amounts to about $\$ 200$ a year, or about 66 cents a day. It is evident, therefore, that the replacing of parts in the expeller costs less than the press cloths for a press.

It is estimated that the presses will deliver 1,400 pounds of oil in a 24-hour run, which is the oil equivalent of about 1,000 bushels of corn when degerminated by the wet process. The expeller will deliver 3,000 to 4,000 pounds of oil in 24 hours, or the equivalent of 2,400 to 3,000 bushels of corn. The capacity of the expeller, therefore, is much greater than that of the press. However, the power required to operate the expeller is much greater, and the depreciation of the machine is also greatly in excess of that of the presses. The one great advantage of the press over the expeller is the exceedingly low upkeep and the practically indestructible character of the machine.

\section{HANDLING AND DISPOSING OF THE CRUDE OIL.}

\section{FILTERING.}

Crude corn oil as it comes from the exyellers or presses is pumped through filter presses, which remove the fine meal and other sediment which has had time to settle. It is then placed in storage tanks until shipped.

BUYING AND SELLING.

Operators who do not themselves refine the oil sell it to refiners, soap makers, brokers, and in some cases to bakers. The use of crude corn oil for industrial and edible purposes will be considered later. The price obtainable depends largely on the grade of the oil, and especially on the amount of free fatty acids present. Prime crude oil is usually limited to not more than 2 per cent of free fatty acids. The next lower grade must not as a rule contain more than 3.5 per cent. Refiners protect themselves from a heavy refining loss by paying less for an oil which contains such acids in excess of the specified quantity. Under normal operating conditions with average corn the crude oil contains from 1 to 3 per cent of free fatty acids. It appears that the oil from wet-process germs has a somewhat higher percentage of free acids than that obtained from dry-process germs.

Large refiners, in order to have enough to supply the demand for their refined oil, have found it profitable to buy considerable quantities of the crude oil and refine it in addition to their own production. Producers who market their refined oil as package goods for the retail trade find this practice especially desirable in order to supply the demand created by their extensive advertising. This practice 
of the large refiners has furnished a valuable outlet for the crude oil of producers who for one reason or another have not installed refining equipments.

The starch and hominy plants which do not refine their oil or sell their entire output to other producers dispose of the crude oil mostly to brokers and soap makers.

\section{HANDLING AND DISPOSING OF THE OIL CAKE.}

The oil cake from corn germs has a well-recognized feeding value. As previously stated, it contains from 5 to 7 per cent of fat when obtained in hominy mills and from 8 to 12 per cent when produced in starch plants. When this cake is ground and mixed with feed products the fat content of the resulting mixture ranges from 3 to 6 per cent. Practically all the oil cake is utilized for this purpose. The bran and husks and the poorer quality of meal must be disposed of as feed and is sold by the dry millers under the name of "hominy feed." The starch makers produce a feed which they usually call "gluten feed." This gluten feed generally carries a guaranty of about 20 per cent of protein. All the feeds are marketed under a guaranty as to the content of fat. The feed stock from the hominy mills (see fig. 2) can be sold separately because it has sufficient fat, but when mixed with the bran and husks it becomes necessary to add the oil cake in order to bring the fat content up to the amount expected in feeds. It is generally stated that the value of a feed, in so far as it is reflected in the price, depends mostly on the protein content and not so much on the fat content. Thus, a feed with 6 per cent of fat would not bring an appreciably greater revenue than one containing only 5 per cent. Hence, an excessive amount of oil in the cake is carefully avoided.

The question of color is important with regard to feed. Although a dark color has no effect on the feeding value, it immediately affects the price, because buyers are accustomed to a light-colored feed. Excessive pressure in the expeller, which insures a maximum yield of oil, so darkens the cake that it is thought the reduced price obtainable for the feed because of the darker color may perhaps offset the gain in the yield of oil. At one plant where hydraulic presses are in operation the oil cake is not mixed with the feed, but is sold separately as a dairy feed.

The question of extracting the oil from the cake by means of solvents and thus removing all the oil has in recent years received considerable attention, owing largely to the high price of corn oil. It is understood that already such extracting systems are being operated by several large corn-oil producers. Just how the removal of all or nearly all the fat from the germ would affect the feed problem 
is a question; but since the removal of practically all the fat would concentrate the protein to some extent, it would seem, in view of what has been said regarding the relative value of protein and fat in feeds, that the feeding value would not be greatly diminished.

\section{BUYING AND SHIPPING CORN GERMS.}

Until a few years ago there was considerable trade in corn germs, but this has almost entirely disappeared because no germs are to be had. The attractive prices for oil have induced many manufacturers of corn products, who formerly disposed of the germs to others, to install expelling units and thus add a material source of profit to their business. The very fact that there was a brisk demand for the germs by oil manufacturers was convincing evidence that the expelling of the oil was a profitable operation.

Some difficulty is encountered in the shipping of corn germs because of their tendency to spoil in transit, and the loss incident to such spoilage has somewhat discouraged the practice. The germs are shipped in bags, and with rapid shipment and the proper control of moisture the spoilage can be reduced to a minimum.

\section{UTILIZATION OF CORN OIL.}

Corn oil has been used to a greater or less extent for most technical purposes for which other vegetable oils are used. One of the principal technical uses for which it has been in good demand is in the preparation of rubber substitutes, for which it seems to be well adapted. Both crude and refined oils are used for this purpose.

Corn oil is still used in considerable quantities for soap making, this being one of the principal uses for the poorer grades, which can not be refined except at a large loss. The oil is very well adapted for making soft soaps, but it is not so suitable for the harder and better quality of soaps. The foots obtained on refining the crude oil are, of course, used exclusively for soap making.

It is reported that com oil has been used in wool spinning where a cheap noncombustible oil is demanded. The present price, however, probably makes it uneconomical for that purpose. The iodin number also would indicate that it might not be entirely safe.

In the manufacture of lubricants, com oil has had a limited application. For this purpose it has not been used alone, but has been mixed with blown rape oil and mineral oil. However, the fact that it has a tendency to gum makes it unsuitable ior this purpose, and its use in lubricants has practically ceased.

Corn oil is classed sometimes as a nondrying oil and sometimes as a semidrying oil. Its iodin value might place it in the semidrying class, but it has few drying properties and does not form a hard 
film. Its use in paint, therefore, has been limited to the cheap grades of barn paints, when combined with other and better drying oils. This use is also rapidly declining and will no doubt be entirely discontinued if the price of the oil remains high.

When corn oil was first produced in marketable quantities it was used exclusirely for technical purposes. Gradually, however, as refining methods were improred and the demand for edible oils increased, the oil was direrted to edible purposes until at present probabl 75 per cent of the total output is utilized in that way. It is in demand for practically all purposes for which cottonseed oil is used, and the producers, brokers, and refiners are confident that in time all the com oil of good quality will be used for edible purposes.

The shortage and the high price of olive oil during recent years hare serred to stimulate the use of other regetable oils for salad-oil purposes, and com oil is being sold in increasing quantities to meet this demand. In line with this derelopment its use in cookery has also been increased. The sale of refined corn oil for household purposes is at present limited almost entirely to a few firms.

Corn oil can be heated to a relatively high temperature without smoking or dereloping an odor and does not darken as readily as some other edible oils. In this connection it may be mentioned that there is a conviction that in cookery it is more economical to use liquid fats than solid fats, because there is less waste. It is easier to measure the necessary quantity when the material pours than when it is solid; consequently excess fat is more easily aroided.

There seems to be some difference of opinion among bakers regarding the adaptability of corn oil for shortening in crackers and bakery goods. The refined oil is used to some extent for this purpose and is said to gire results similar to those obtained with cottonseed oil. Some takers are inclined to beliere that its use is limited because of its yellow color, such color being undesirable in the manufacture of white goods like soda crackers. For sweet goods the oil is usually used blended with other regetable oils. In bread it is also used by some bakers when mixed with lard.

The general impression gained from interriews with large bakers is that the future of refined corn oil in the baking industries is assured. The principal reason why it is not used more generally at present is because it is not obtainable at all times in sufficient quantities. The bulk of the refined oil is marketed as package goods for the retail trade; therefore for the bakers only such quantities are arailable as are not needed to satisfy the retail demands. A considerable increase in the production of the refined oil could no doubt easily be absorbed in this field prorided the price compared farorably with that of other oils suitable for the same purpose. 


\section{EFFECT OF COLOR AND CONDITION OF THE CORN ON THE YIELD AND CHARACTER OF THE OIL.}

Both white and yellow dent corn are used in this country for the manufacture of com products, but the white seems to be generally preferred. In hominy mills the variety used is determined largely by the kind of corn meal demanded. Certain sections of the country consume only yellow corn products, while others prefer the white. Starch and glucose makers use both kinds, most operators claiming that the products are the same. There is no indication that there is any difference in the oil from the two kinds, but it is the opinion of some that the white corn has a larger germ and hence produces more oil to the bushel. This opinion is based largely on conjecture.

The opinion seems to be quite general, especially among the drycorn millers, that the quantity of oil obtainable decreases somewhat with the age of the corn. Their theory is that the oil "creeps" out of the germ into the starchy portion of the kernel and is thus lost in the hominy products and feed. No definite study of this question seems to have been made. It is possible, however, that with age and the drying of the kernel the germ becomes more brittle and thus chips and breaks more in the degerminators, the smaller fragments being lost in the feed. The monthly oil records for a number of years of one starch and glucose plant were carefully examined, and it was found that the quantity of oil in the corn, calculated on a moisture-free basis, was about 4.3 per cent, as determined by extraction with carbon tetrachlorid. The corn milled during the summer months was somewhat higher in oil content. While the increase was only about 0.3 per cent, it was shown by the records that this increase occurred every year. As a rule, the corn used in the summer months is the last of the previous year's crop. It would seem, therefore, that if the general assumption is true that the older corn yields less oil, it is not because there is less oil in the kernel, but because the degerminating is less efficiently performed on the older corn. In the dry process of degerminating, this is very likely to be the case.

The condition of the corn with regard to its maturity has a pronounced effect upon the character of the oil and the quantity obtainable. According to figures available at one of the glucose plants, the soft corn of 1917 had a somewhat higher oil content than wellmatured corn, but the general experience with that year's crop showed a decidedly reduced yield. The explanation usually advanced is that some of the oil was distributed in the kernel outside of the germ and was lost. A most interesting feature of this oil was its high acid content. While normally the oil averages between 
1 and 2 per cent of free acids, the oil from the 1917 crop areraged nearly 10 per cent and in many instances was as high as 15 to 17 per cent. It was also darker than usual and the expelling was more difficult, in some cases more than 15 per cent of the oil being left in the cake. Naturally the refining of this oil inrolred big losses, and consequently it brought a greatly reduced price in the crude state.

\section{COMPARISON OF THE OIL-PRODLCTION OPERATION IN DIFFERENT MILLS.}

In order to ascertain the extent to which the products from the rarious mills differed, determinations were made of the fat and moisture content of the germ, oil cake, and feed secured from these mills, and samples of the oils they produced were tested for free fatty acids. Table I shows the results.

TABLE I.-Comparison of the fat. moisture, and free fatty acid content of material produced. in representative corn-products mills in the Lnited States, shouing the results of the wet and dry processes of degerminating the kernels.

\begin{tabular}{|c|c|c|c|c|c|c|c|c|}
\hline \multirow[b]{2}{*}{ Material analyzed. } & \multicolumn{8}{|c|}{ Source of material, different mills (per cent). } \\
\hline & 1 & 2 & 3 & 4 & 5 & 6 & 7 & $\begin{array}{l}\text { A verage } \\
\text { of } 7 \\
\text { mills. }\end{array}$ \\
\hline 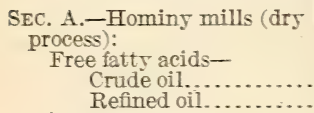 & $\begin{array}{r}1.29 \\
.10\end{array}$ & 0.78 & 0.73 & 0.88 & 2.34 & 1.27 & 0.88 & 1.11 \\
\hline 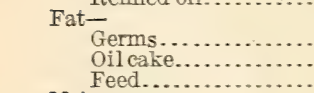 & 5.93 & $\begin{array}{l}13.3 \\
5.80 \\
6.36\end{array}$ & $\begin{array}{r}14.37 \\
4.19 \\
6.15\end{array}$ & \begin{tabular}{l}
15.68 \\
$\cdots$ \\
\hdashline .23
\end{tabular} & $\begin{array}{r}22.41 \\
7.90\end{array}$ & $\begin{array}{r}16.66 \\
9.38\end{array}$ & $\begin{array}{r}24.90 \\
a 12.97\end{array}$ & $\begin{array}{r}17.88 \\
6.82 \\
5.92\end{array}$ \\
\hline 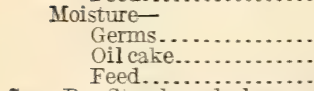 & 12.50 & $\begin{array}{r}2.92 \\
3.37 \\
10.35\end{array}$ & $\begin{array}{r}8.66 \\
10.55 \\
12.66\end{array}$ & $\begin{array}{r}7.90 \\
10.86\end{array}$ & $\begin{array}{r}8.49 \\
7.96 \\
10.36\end{array}$ & $\begin{array}{l}9.61 \\
4.45\end{array}$ & $\begin{array}{l}4.31 \\
2.74\end{array}$ & $\begin{array}{r}6.96 \\
5.81 \\
11.35\end{array}$ \\
\hline 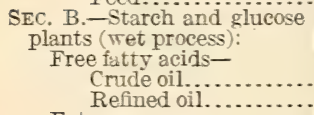 & 1.78 & b 9.17 & $\begin{array}{r}1.39 \\
.17\end{array}$ & 1.65 & $\begin{array}{r}5.34 \\
.11\end{array}$ & $\begin{array}{r}2.14 \\
.10\end{array}$ & 2.05 & 2.39 \\
\hline $\begin{array}{l}\text { Fat }- \text { Germs .......... } \\
\text { Oil cake........ } \\
\text { Feed.......... }\end{array}$ & $\begin{array}{r}51.85 \\
8.90 \\
. .6\end{array}$ & $\begin{array}{r}c 23.78 \\
8.08 \\
6.85\end{array}$ & $\begin{array}{r}41.99 \\
7.35 \\
3.63\end{array}$ & $\begin{array}{r}22.35 \\
9.25 \\
5.20\end{array}$ & $\begin{array}{r}50.14 \\
a 6.04 \\
2.85\end{array}$ & $\begin{array}{r}55.96 \\
8.35 \\
3.36\end{array}$ & $\begin{array}{l}49.20 \\
10.30\end{array}$ & $\begin{array}{r}42.23 \\
8.70 \\
4.38\end{array}$ \\
\hline 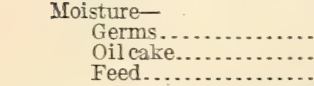 & $\begin{array}{r}3.75 \\
9.74 \\
11.12\end{array}$ & $\begin{array}{l}5.46 \\
9.20 \\
9.53\end{array}$ & $\begin{array}{r}4.68 \\
7.89 \\
10.38\end{array}$ & $\begin{array}{l}4.38 \\
3.80 \\
8.91\end{array}$ & $\begin{array}{r}4.62 \\
7.15 \\
11.22\end{array}$ & $\begin{array}{r}2.28 \\
9.76\end{array}$ & $\begin{array}{l}5.44 \\
8.67\end{array}$ & $\begin{array}{r}4.37 \\
7.74 \\
10.15\end{array}$ \\
\hline
\end{tabular}

a Not included in arerage. $b$ Immature corn of 1917, not included in average. $c$ Immature corn of 1917.

A study of Table I shows that there is a wide variation in the character of the material produced in the rarious mills. While the percentage of free fatty acids in the oils is low it is evident that the oil obtained from germs separated by the dry process of degerminating is somewhat lower than that from the wet process. This might be expected from the nature of the two processes. So far as obserration indicates, however, the refined oil from the two processes shows no noticeable difference. The percentages of fat in the germs and oil 
cake, as indicated by the arerages, agree fairly well with the opinions expressed by the operators of both types. Since the moisture content may be much affected by the age of the material and the conditions under which it was shipped, figures relating to the percentage of moisture may not necessarily be indicative of actual conditions.

Attention is directed to some of the figures in section A of Table I. Mill 2 furnished germ material of exceedingly low fat content. This mill also reported a low yield of oil from a bushel of corn. It is evident, therefore, that the degerminating was not efficiently performed. Mill 7 shows an excessive percentage of fat in its oil cake, but also a germ material greatly above the average in fat content, indicating a good separation-of germs, but probably less efficient handling of the expeller.

\section{ECONOMICS OF CORN-OIL PRODUCTION.}

To determine the cost of producing corn oil is exceedingly difficult, and no producer was found who had any clear idea as to just what it cost him or how to determine the cost. The difficulty lies in the fact that in the general processes of making hominy and starch the removal of the germ is a necessary factor in obtaining the best products. This cost, therefore, should be charged to those products in the manufacture of which it is a necessary process and not to the cost of producing the oil. The cost of the oil production should be calculated only on the operations involved after the germs have been separated. Thus, in the dry process the cost charges for the oil should begin after the germs have passed through the hominy reels and the fine meal removed. In the wet process the germs must be washed several times in order to save the adhering starch, and the cost charges for the oil should therefore begin with the expelling of the moisture. If the net revenue from corn oil is to be compared with that obtainable when the germs are disposed of as feed, the cost of expelling the moisture and drying must be eliminated, since both operations are necessary in order to prepare the germs for feed. The cost, therefore, of producing corn oil in the industries here described is limited to the cost of expelling the oil and preparing it for market.

\section{COST OF EXPELLING CORN OIL.}

Among starch manufacturers the impression seems to prevail that the cost of expelling corn oil approximates half a cent per pound of oil. Since the cost per pound depends on the amount of oil obtained from a given quantity of germ material, it follows that the greater the fat content of the germ the lower the cost per pound of oil will be. Consequently, the character of the germ material as regards the presence of foreign matter is an important factor. For this reason it will cost more per pound to expel the oil from dry-process germs 
than from wet-process germs, because the same quantity of material yields much less oil over which to distribute an equivalent operating cost.

In an effort to determine as nearly as possible the actual cost of producing corn oil, based on the cost of equipment and of operating the same, the figures in Table II are submitted. The cost of the equipment is, of course, an estimate based on present-day prices. The cost of repairs on expellers and the items of labor, power, and productive capacity were obtained from a careful study of the operation of a 4-expeller unit in a typical hominy plant.

TABLE II.-Itemized estimate of the cost of the process of producing corn oil.

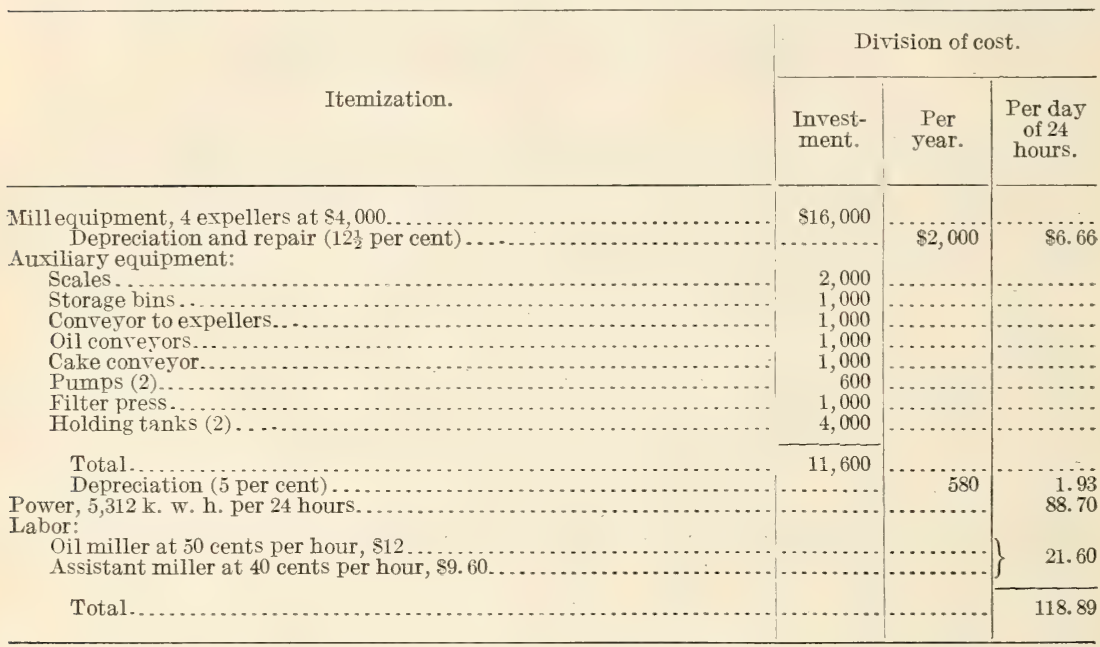

Production.--Per machine, 3,000 pounds of oil in 24 hours, 12,000 pounds: Cost per pound $(\$ 118.89 \div 12,000), 0.99$ cents.

These figures are intended to show approximately what it costs to expel corn oil in connection with hominy plants where the necessary floor space may be arranged for without the construction of an additional building. Overhead charges, such as management and selling organization, are not included. It seems probable that the installation of an expelling plant such as is here outlined would not necessitate any material addition to the pay roll except for the labor required to operate the machines. Although in making an actual cost accounting the charge for overhead expense should be included, the amount thus chargeable would be so difficult to ascertain, owing to the fact that the expelling is so involved in the other operations of the plant, that to include it here would be largely guesswork. It is evident that if an independent plant were operated exclusively for the expelling of corn oil the heavy orerhead expense 
of management and office organization would almost certainly make the operation unprofitable.

Assuming that the foregoing estimate of approximately 1 cent is the cost to produce 1 pound of oil in the average hominy plant (dry process), it is possible to arrive at the cost for similar operations in starch or glucose plants (wet process). As previously stated, the wet-process germs yield approximately three times as much oil as the dry-process germs. The cost to produce a pound of oil in a starch plant would be, therefore, about a third of a cent. Some operators in starch plants were of the opinion that the cost would approximate half a cent a pound.

Table III gives a comparison of the revenue that may be obtained by disposing of the germ material for mixing with feed and by expelling the oil and returning the oil cake to the feed.

TABLE III.-Comparison of the revenue obtainable from the germs from 1 bushel of corn when disposed of respectively as feed and when used for oil expelling in either starch or hominy mills.

\begin{tabular}{|c|c|c|}
\hline Items. & $\begin{array}{l}\text { Wet } \\
\text { process } \\
\text { (starch } \\
\text { mills). }\end{array}$ & $\begin{array}{c}\text { Dry } \\
\text { process } \\
\text { (hominy } \\
\text { mills). }\end{array}$ \\
\hline Germs obtained from 1 bushel of corn.......... & 3.47 & 4.17 \\
\hline Revenue from germs sold as feed, at 2.5 cents a pound.................................... & 8.40 & 10.42 \\
\hline 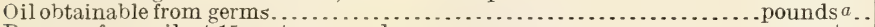 & 1.25 & .5 \\
\hline Revenue from oil, at 15 cents a pound. . . . & 18. 75 & 7.5 \\
\hline Oil cake obtainabie.... & 2.22 & 3.67 \\
\hline Revenue from oil cake, at 2.5 cents a pound & 5.55 & 9.17 \\
\hline  & $\begin{array}{r}24.30 \\
c .63\end{array}$ & $\begin{array}{c}16.67 \\
d .5\end{array}$ \\
\hline 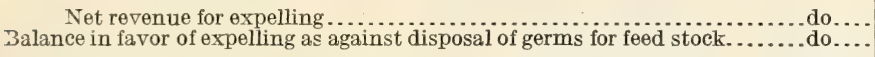 & $\begin{array}{l}23.67 \\
15.27\end{array}$ & $\begin{array}{r}16.17 \\
5.75\end{array}$ \\
\hline
\end{tabular}

$a$ Since the percentage of oil obtainable by expelling the germs varies greatly, only the average is here used.

$b$ The weight of oil cake obtainable is here calculated simply as the difference between the weight of the germs used and that of the oil removed. For example, 100 pounds of dry-process germs are considered as yielding 12 pounds of oil and 88 pounds of oil cake. Although not absolutely accurate, it is considered sufficiently so for the purpose here intended. However, if by actual fat determination the germs are found to contain 18 per cent of oil and the cake 6 per cent, the following formula should be used to determine the exact weights of oil and oil cake obtained, thus: $[6(100-a) \div 100]+a=18$ pounds (total oil present in 100 pounds of germs), in which $a$ represents the actual number of pounds of oil which will be obtained. Upon solving this equation it is found that 12.766 pounds of oil are obtained, and 87.234 pounds of oil cake containing 6 per cent of fat.

$c$ At one-half cent per pound.

d At 1 cent per pound.

The figures in Table III are intended to be only approximations, since several factors have not been considered which might increase slightly the cost of producing the oil. The fact that the germ material for expelling must be made more dry than that for feed purposes will add slightly to the cost. The material would also probably be reduced or ground to a greater extent than if intended for feed. These operations are not expensive, however, and since the actual cost is difficult to estimate they have been omitted from the calculations. The efficiency with which the degermination and expelling 
are accomplished is a determining factor. A good grade of corn and careful operation of the expellers are also necessary to obtain the margin of profit indicated. The price of corn feeds is of course dependent upon the cost of corn, and consequently the lower the price of corn and feed the greater the balance in faror of oil expelling, prorided the price of the oil remains the same.

Table IT gires data comparing the respectire weights of oil left in the oil cake obtained from a bushel of corn br the two trpes of mills.

TABLE IT.-Comparison of oil left in the oil cake obtained from a bushel of corn witien operating on dry-process and wet-process germs. ${ }^{a}$

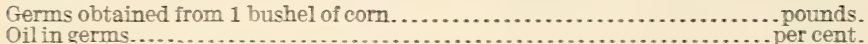

Oilleft in cake.

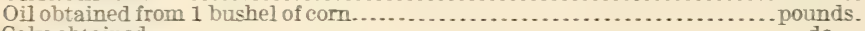

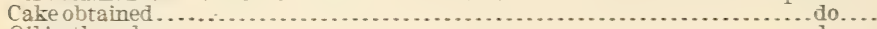

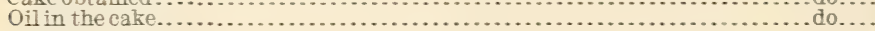

\begin{tabular}{|c|c|}
\hline $\begin{array}{l}\text { Dry } \\
\text { process } \\
\text { (hominy } \\
\text { mills). }\end{array}$ & $\begin{array}{l}\text { Tet } \\
\text { process } \\
\text { (starch } \\
\text { and } \\
\text { glucose } \\
\text { plants. }\end{array}$ \\
\hline $\begin{array}{c}4.17 \\
18 \\
6 \\
.532 \\
3.637 \\
.2182\end{array}$ & $\begin{array}{l}3.47 \\
45 \\
9 \\
1.372 \\
2.097 \\
.1867\end{array}$ \\
\hline
\end{tabular}

a The calculations in this table were made with the formula explained in footnote $b$ of Table III.

It is erident that in expelling drr-process germs a slightl 5 greater loss of oil results than when expelling wet-process germs, although the percentage of oil left in the cake is considerabls lower.

\section{PRODUCTION OF EDIBLE OIL. ${ }^{1}$}

In 1919 there were 22 corn-oil producers in the United States, but early in the rear sereral of these had suspended operations on account of adrerse economic conditions. Of the 20 producers only four, so far as is known, turned out refined or edible oil, one being a homins miller and the other three starch and glucose manufacturers. This small number of refiners, howerer, is no indication of the relatire quantity of oil which is refined for food purposes. According to Bailer and Reuter, ${ }^{2} 111,000,000$ pounds of corn oil were produced in 1918 , of which approximatel $76,000,000$ pounds, or about 70 per cent, were refined for edible purposes.

It is the practice of a few of the large operators to refine not only the oil which is produced in their own plants, but also to bur large quantities of crude oil from other producers for refining. Companies

\footnotetext{
1 Since this paper deals mainl w with the production of crude corn oil as a br-product in the corn-milling industry, the refining of such an oil for edible purposes. Which is an industry in itself is here discussed onl? in a general $\pi a r$. A technical paper embodring the results of a detailed studs of the preparation of edible corn oil mas be issued later.

2 Baike, Herbert S., and Reuter, B. E. The production and conservation of fats and oils in the Tnited States. U.S. Dept. of Agr. Bul. 769, sup., p. 4. 1919.
} 
which have developed a large package trade find it necessary to do this in order to supply the demand created by their extensive advertising.

Crude corn oil as a rule is a fairly good product, especially that produced from dry-process germs, and in some cases it can be used for edible purposes without refining. The oil possesses a peculiar cereal-like odor and taste, which is not unpleasant in itself, but is undesirable when the oil is intended for salad or cooking purposes. The color is a deep yellow, which also must be removed from oil which is intended for food purposes.

The processes used for refining, bleaching, and deodorizing are in generalsimilar to those employed for other vegetable oils. The crude oil is first treated with alkali in large refining kettles (fig. 10), the amount of alkali used depending on the quantity of free fatty acids present. This treatment almost, if not entirely, neutralizes the oil, removes albuminous matter, and lightens the color to

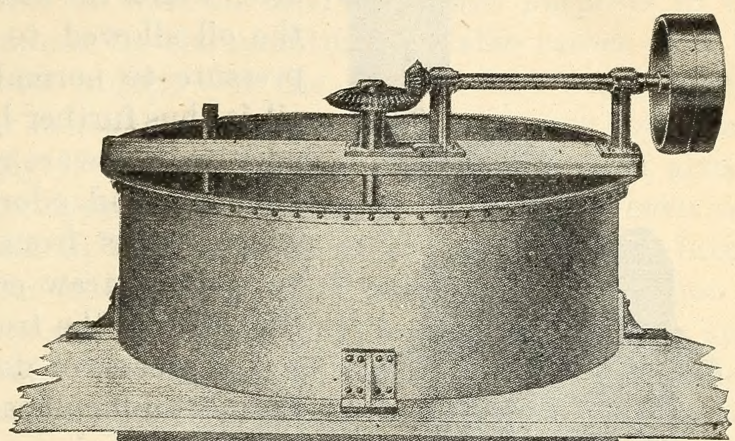

some extent. The oil is then separated from the foots, the latter being disposed of to soap makers. The neutralized oil is heated sufficiently to dehydrate it, after which it is partially bleached by the addition of about 5 or 6 per cent of fuller's earth, with constant stirring. After the oil and fuller's earth have been thoroughly mingled, the mixture is pumped through filter presses to remove the earth, and the filtered oil is pumped into the deodorizing 
tank. (Fig. 11.) The treatment received in this tank is of great importance. Essentially this treatment consists of heating the oil to about $400^{\circ} \mathrm{F}$. under vacuum by means of steam jackets and steam coils, superheated steam being used in these coils. Through

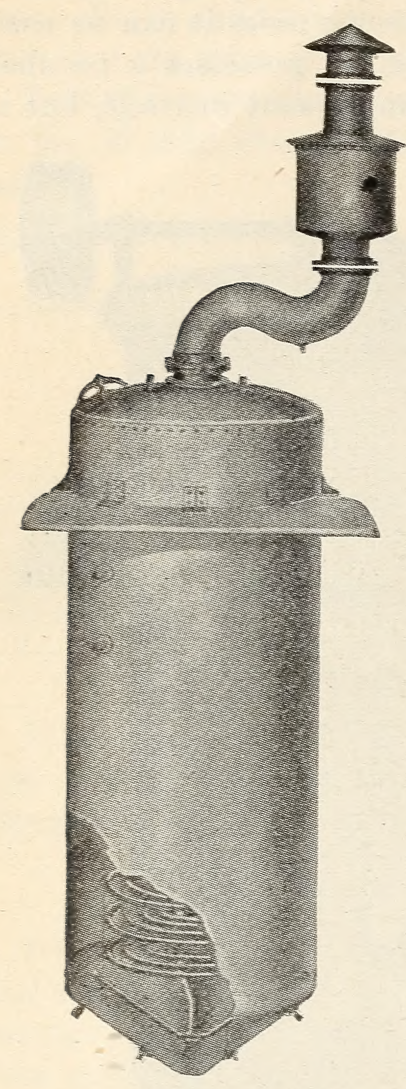

FIG. 11.-Type of tank used for deodorizing corn oil. These tanks are also constructed with jacketed bottoms for steam heating. a secondary coil with perforations, superheated steam is passed into the oil. This treatment is continued for several hours, after which the steam is turned off and the oil allowed to cool under reduced pressure to normal temperature. The oil is thus further bleached, the peculiar odor and taste are removed, and a bland, tasteless, and odorless oil is produced which varies from a pale yellow to a very light straw color, according to the efficiency of the treatment.

The process of deodorizing constitutes the most difficult part of the several processes required to produce edible corn oil, and the details of the operation vary considerably in the several refining plants. Questions of temperature and time of treatment are determined largely by experimentation and the experience of the men in charge. The character of the crude oil used is also in some cases a determining factor.

After the oil is cooled in the deodorizer it flows or is pumped into the storage tanks. While in storage it is in some cases kept at a low temperature in order to effect the separation of stearin, which, however, does not separate from corn oil to the same extent as from some other vegetable oils. Finally, the oil is filtered through coarse paper or cloth to clarify and brighten it, especially when intended for the retail trade.

\section{THE FUTURE OF CORN OIL.}

So far as can be concluded from the survey of the industry, corn oil appears to have established itself as a satisfactory product for which there will be a steady demand in the trade. That the oil can always be produced is assured by virtue of the fact that it is a byproduct of the manufacture of certain staple corn products, and it is only in case of an overproduction of fats and oils that it might be discontinued and the germs disposed of as feed. Such a situation 
seems improbable, however, and at the most would doubtless be only temporary. As to the utilization of corn oil, the consensus of opinion among those who are in position to know seems to be that within a few years the oil will be used almost entirely for edible purposes, except only that which is of such poor quality as to make its refining unprofitable. The sale of the oil in retail packages will very likely be further developed, and its use by bakers is also likely to increase. The amount of corn oil used for edible purposes in the future will be determined by the quantity available rather than by any question as to its utility. At the present time some bakers, while admitting that it is suitable for their products, use cottonseed oil because the supply of corn oil fluctuates so that it is not always obtainable in sufficient quantities. Although the supply is even now inadequate it is liable to become more so in the immediate future because of the decline in the brewing of beer. The elimination of the breweries removes one of the principal markets for hominy grits and flakes, and therefore the milling of degerminated corn is likely to decrease. As previously stated, several plants shut down in the winter of 1919. This was due in part, however, to the fact that at the close of the war there was on hand an oversupply of corn meal and flour. According to Bailey and Reuter ${ }^{1}$ there was a decrease in 1918 of 7,000,000 pounds of corn oil, and the 1919 production may show a further decrease. It is certain that the demand in this country for corn meal and flour is not sufficient to make a steady market for such products. In the Southern States, where the use of corn products is much more general than in other sections of the country, the supply is largely derived from mills which do not degerminate the corn and hence produce no oil. It must not be understood, however, that the elimination of the breweries entirely removes the market for brewers' grits, for in the manufacture of nonalcoholic cereal beverages the same material is required, but this market already exists, and there would need to be a great increase in the consumption of such beverages to make up for the decline resulting from the discontinuance of beer brewing. The economic situation with regard to sugar also may be an important factor. The increased demand for corn sirups and other saccharine products may result in an increased milling of degerminated corn. 
